Article

\title{
Protection of Design in the Textile Industry in Order to Improve the Economic Aspect of Sustainable Development of Serbia-Comparative Overview of the Laws of the European Union and Croatia
}

\author{
Nadežda Ljubojev ${ }^{1}$, Marijana Dukić-Mijatović ${ }^{2}$, Mila Zakin Kavalić ${ }^{1, *}$, Sanja Stanisavljev ${ }^{1}$ and \\ Mirjana Cvijić ${ }^{3}$ (I) \\ 1 Technical Faculty “Mihajlo Pupin” Zrenjanin, University of Novi Sad, 23000 Zrenjanin, Serbia; \\ nadezdaljubojev@gmail.com (N.L.); sanja.stanisavljev@tfzr.rs (S.S.) \\ 2 Faculty of Economics in Subotica, University of Novi Sad, 24000 Subotica, Serbia; \\ marijana.dukic.mijatovic@gmail.com \\ 3 Faculty of Technical Sciences, University of Novi Sad, 21000 Novi Sad, Serbia; cvijic.mirjana@gmail.com \\ * Correspondence: mila@tfzr.uns.ac.rs; Tel.: +381-611-400-314
}

Received: 8 February 2019; Accepted: 2 April 2019; Published: 10 April 2019

check for updates

\begin{abstract}
The authors analyze the protection of industrial design in Serbia, with a comparative overview of the rights of the European Union (EU) and Croatia in industrial property law. In addition to the protection of registered design, the protection of unregistered design within the framework of industrial design rights is characteristic of the EU. The unregistered design is acquired without a formal registration procedure, an appropriate disclosure of public design in the EU area. Based on analogy, an initial premise can be established, whereby, after Serbia's entering into the EU, as well as after joining the EU, physical and legal persons from Serbia will have at their disposal several different forms of industrial design protection and unregistered community design. This form of design protection can be significant for the fashion industry in Serbia characterized by a constant dynamic design change.
\end{abstract}

Keywords: comparative overview; Croatia; European integration; registered design; Serbian textile industry; unregistered design

\section{Introduction and Background}

As a developing country, Serbia is in a constant race with the world economy in all spheres of industry, as well as in the textile industry. The poor financial situation of small- and medium-sized enterprises affects the insufficient application of appropriate technology, which is reflected in the stagnation of the textile industry in Serbia. Investing in knowledge and sharing it can replace these weaknesses and affect an innovative way of business dealings and finding creative alternatives [1].

The textile industry in Serbia is faced with numerous problems that affect and slow down growth and competitiveness in all spheres of business. All these problems affect one another and are certainly reflected in the protection of the design and condition of the textile industry in Serbia. The companies coming from transitional countries in general, as well as Serbian companies, have problems with the quality of their business and productivity. An inherited inefficient production system, and transitional recession, common for all countries in transition, influence those companies and have a role in their insufficient competitive capacity. The fact is that Serbian companies have been uncompetitive on the international market for a long period of time. In addition to old technology, poor quality, unattractive packaging, generally high prices, and slow response to market demands are the main reasons for the 
non-competitiveness of Serbian products [2]. The least competitive are the textile and manufacturing industries, as well as the metal and electronics industries, where there has been no technological reconstruction for years. The average machine age in Serbia is 30 years old. Comparing to the situation in the region, this is a delay of about 12 years. The greatest backwardness was noted in textile companies ( 35 years), followed by the machine industry (34.5 years) [3].

The contemporary market of textile enterprises in Serbia is characterized by unfavorable aspects which are reflected in the poor positioning of textile enterprises in the global market, reduced competitiveness, lack of technology, lack of staff training, lack of standards, and others. For many years, this sector has had the lowest average net salary in Serbia and it faces difficulties in operating because of an unfair competition (the gray economy in the textile sector was $44 \%$ at the national level and $50.5 \%$ of total turnover in the south of Serbia) [4]. Accordingly, the market in Serbia is poorly developed, and consumers are not sufficiently educated and informed about their rights, as well as in the ways they are exercised. In particular, due to many years of isolation and sanctions, Serbian consumers developed an extremely high degree of tolerance on the placement of counterfeit and pirated goods [5].

Based on the agreement between the European community and the Republic of Serbia on trade in textile products [6], the results achieved in this branch of the Serbian economy are evident. Serbia exports $70 \%$ of textiles and footwear to EU countries [7]. With the forced entry into the transitional trade agreement with the EU, and the free trade agreement between Serbia and Turkey, [8] as well as thepossibility of applying diagonal accumulation of goods originated in Turkey, Serbia, EU, and Central European Free Trade Agreement (CEFTA) countries, a market of nearly 800 million consumers is provided to entrepreneurs from this sector. Serbia, having concludedallfree trade agreements, is becoming an attractive destination for EU customers, as well as countries in the region [7].

The European textile sector employed some 1.7 million people in 2015 [9]. The European textile industry is becoming increasingly innovative and competitive, and it plays a significant role in economic development. Today, the 'Innovation Union 2020'strategy puts design at the very heart of innovation drivers [10]. Faced with competition from low-cost countries such as China and India, European manufacturers working in this industry have to care about quality and follow current trends, as well as meeting ever-increasing customer expectations, which should lead to the growth of the economic value of this sector [11]. This is why there is a clear interest from the member states and candidate countries in substantially strengthening the industry on a European and even global scale $[9,11]$. In the following member states the relative share of the textile industry in the total production is significantly higher: Bulgaria (22\%), Portugal (20\%), Romania (16\%), Lithuania (15\%), Latvia (12\%), Estonia (11\%), Croatia (10\%), Italy $(9 \%)$, and Greece $(9 \%)$. In 2015 , the EU textile and clothing industry reached a turnover of 169 billion euro's, an increase of $1.4 \%$ in relation to the previous year [11]. The EU is currently the second largest (after China) exporter of textiles and clothing in the world ( $24 \%$ and $26 \%$ of world sales) [9]. Italy is the largest exporter in the European textile sector, accounting for $35.6 \%$ of total EU exports, followed by Germany, France, and the United Kingdom; however, their total share in exports is only $10 \%$ [12].

In 2014, a year after Croatia's accession to the EU, textile production increased by $38 \%$ to a total of 84 million euro's [13]. About 1500 companies currently operate in the Croatian textile sector, generating $4 \%$ of employment and average monthly salaries of around 586 euro's [14].

Croatia is not far from Serbia in terms of its geographic location and, unfortunately, problems in the textile industry. Both countries are still undergoing a transition process; they have a high public debt, inefficient public sector, and structural imbalances; they were severely harmed by the global financial crisis. The Global Innovation Index for the period from 2013 to 2016 for countries in transition points to the fact that both Serbia and Croatia, which are beside each other in the table, did not experience growth. What makes Croatia and Serbia economically similar, aside from their former long mutual Yugoslavian history, can be limited to the existance of recidivation of state socialism, stagnant 
economic growth in recent years, and the high public debt of both countries. Both countries struggle with problems of counterfeiting and piracy.

In the study which was conducted by the Organization for Economic Cooperation, and Development (OECD) and the European Union Intellectual Property Office (EUIPO), the results show that trade counterfeit and pirated goods amounted to $2.5 \%$ of world trade in 2013 . This was even higher in the EU context where counterfeit and pirated goods amounted to 5\% of imports [15]. Data from the World Intellectual Property Organization (WIPO) indicate that, in absolute numbers, residents of China filed almost 650,000 industrial design rights across the world in 2012, with the next closest residents filing from Germany $(76,369)[16]$.

\section{Methodology}

An in-depth analysis of the comparative advantages of certain types of design is based on data published by the State Intellectual Property Office (SIPO) and the Intellectual Property Office (IPO) in their annual industrial design reports. The analysis used only data for the period 2011 to 2017 in Serbia and in Croatia. The starting year with the beginning of Croatia's accession negotiations with the $\mathrm{EU}$ in the tables is specially marked.

The methods that were used included an analytic-synthetic method and a method of content analysis, methods of scientific research (analogy), and methods of statistical data analysis. An extensive analysis of analogy by its nature is based on an inductive method, as highlighted by Mill [17]. On the other hand, author Nagel in his work 'Structure of Science' defines the analogy that "in any case, people try to use familiar systems of relationships as models by which new areas of experience can be understood" [18].

In addition to design protection, national authorities of EU member states also have the possibility to protect the registered community design. The EU and some of its member states offer broader intellectual property (IP) protection for fashion designers, arising from Europe's reputation as a fashion hub and as a region noted for 'haute couture fashion houses [19]. Legal protection of the community design extends automatically to the new member states.

The protection of industrial design in Croatia (since joining the EU) is possible through the following avenues:

- in the national proceedings before the SIPO;

- in the international procedure conducted through the Hague system of international registration of industrial design (the Hague system);

- registered community design applicable throughout the EU territory (based on the EUIPO procedure);

- Unregistered community design, obtained without a formal registration procedure, by making designs available to the public in the EU.

Today, in Serbia (EU candidate), the protection of industrial design can be achieved through the following avenues:

- $\quad$ in the national procedure before the IPO;

- in an international procedure conducted through the Hague system.

Based on the analogy of legal norms, it can be established that, after Serbia's entering in the EU, as well as after Croatia's EU accession, natural and legal persons from Serbia will have at their disposal several different forms of industrial design protection and unregistered community design. This form of design protection with all of its stated characteristics can be especially significant for the fashion industry in Serbia, which is characterized by a constant dynamic design change. 


\section{Legal and Institutional Framework for the Protection of Industrial Design}

Industrial design, in terms of the right to industrial property, implies the overall visual impression which leaves the product to an informed consumer or user of an aesthetically designed product. An informed consumer or user is a physical person who regularly meets the type of products in question. Industrial design is intellectually good because it is the result of intellectual creative work that can be materialized countless times on industrial or craft products [20]. Accordingly, the purpose of legal regulation of design is in the economic value of aesthetic design of goods, i.e., in recognition of the importance of the attractiveness of nicely designed and equipped products for survival in a competitive struggle, and in the need to legally protect the creative work of aesthetic design [21]. In this sense, the design has not only an aesthetic function but also a function of distinguishing goods from one economic entity from the same type of goods in another economic entity, which is the reason why the right to protect design has elements of copyright and trademark rights [22].

From this, it follows that designing becomes a source of significant revenue; thus, designers have to be provided with legal protection. Under the conditions of a competitive, developed market, man's need for beauty is increasingly reflected; therefore, the product is not only required to be useful and functional but also attractive, to suit the taste of consumers for whom it is intended. The outward appearance of the product becomes even more important in almost all consumer products, from clothing and footwear to household appliances. Industrial design becomes an increasingly recognized social activity, and the team and the results of this act become an increasingly important subject of legal protection [23]. The protection of industrial design promotes creativity in the industrial and artisanal sector, contributes to the expansion of economic activities, and increases the export potential of national products.

Depending on whether the legal protection of industrial design is achieved after the application of an industrial design to the competent state authority and by the implementation of that particular authority of a special administrative procedure, we distinguish a registered and unregistered design.

\subsection{The Terms of Registered and Unregistered Designs}

A registered design is a design protected with exclusive industrial property rights granted in an administrative procedure by an authorized state body. The object of protection is the outward appearance of the product, i.e., the overall visual impression that the product leaves to the informed consumer or user. Industrial design is the three-dimensional or two-dimensional appearance of the entire product or a part of it, determined by visual characteristics such as lines, contours, colors, shape, texture, and/or materials of the product itself or its ornamentation, as well as their combination. Industrial and craft products and packaging are the most important subject of industrial design. However, since the difference is assessed through a one-to-one comparison, a single distinguishing feature such as an embroidered jeans pocket, an oversized zipper, or a dominant print may be enough to produce a unique overall impression and justify the protection either of the extraordinary feature or of the whole item [24]. A product is "any industrial or handicraft item, including, inter alia, parts intended to be assembled into a complex product, packaging, get-up, graphic symbols, and typographic typefaces, but excluding computer programs" (Article 1 (b) Directive 98/71/EC). The subjective design protection right is solely a property right that empowers its holder to prohibit or permit the commercial exploitation of a protected design. The basic design protection requirements are the novelty of design and individual design character [25]. These conditions used to differ depending on the country in question; however, with years of difference, the national regulations were harmonized under the influence of international sources, and this is above all the Hague agreement concerning the international registration of industrial designs since 1960 (The Hague Act (1960)), of which Serbia has been a member state since 1993 [26]. In addition, the EU member states showed great interest in harmonizing the mutual design legislation. Directive 98/71/EC of the European parliament and of the council of 13 October 1998 on the legal protection of designs (Directive 98/71 EC) harmonized national laws on the legal protection of design [27]. Council Regulation (EC) No 6/2002 of 12 December 
2001 on community designs (changed) established a system for the protection of industrial design at the community level [28]. By decision of Chamber No. 2006/954/EC on 18 December 2006 and by Council Regulation (EC) No. 1891/2006 on 18 December 2006, there is a link between the systems for the registration of an industrial design of the EU with the international industrial registration system of the WIPO. In contrast to the United States, in the EU, fashion products (including traditional apparel categories, accessories, and footwear) may be protected under national and EU design laws and national copyright laws [19].

An unregistered design is an industrial design for which legal protection is achieved through the act of making an industrial design accessible to the public, and without carrying out any administrative procedure. The lack of an obligation to register industrial design means that, in the legal regime of unregistered design, care is taken to provide proof related to the origin of the design of a private law nature. The ratio of this legal regime is in the fear that, by discovering design before starting its commercial use, this would become available to competitors that would modify it to the limit of identity and, as such, exploit it economically, which would negatively affect the commercial success of the creator of such a design [29]. Protection of unregistered design within the framework of industrial design rights is characteristic of the EU. According to Council Regulation (EC) No. 6/2002, the right to unregistered design takes three years from the date when the unregistered design was first made available to the public. After these three years, protection cannot be prolonged. Rights based on unregistered design are narrower than rights arising from registered design and relate to prohibiting other persons from copying the design. It is about the area of the fashion industry characterized by a constant dynamic change in design (e.g., clothing and footwear production). An unregistered community design must meet all the requirements set for a registered community design, but a registration application does not have to be filed with EUIPO [30].

Registered and unregistered community designs are afforded different rights in the EU [31]. The differences between the registered and unregistered community design lie in the scope of legal protection, the term of protection, the documents to be filed, and the need for verification of the legal protection. However, a document that can easily prove property is obtained with the registered design. Benefits of a registered community design are practical and financial advantages (primarily saving translation costs and administrative costs). The registered community design provides uniform protection throughout the EU. The registration of the registered design of the community offers the possibility of multiple applications.

Intellectual property protection is significant for most European fashion designs. The industry is "driven by fast-paced innovation embodied in the creation of seasonal collections of new fashion designs. Europe remains the center of haute couture, [32] and the protection of fashion designs is a core part of its cultural identity and legal regime" [33].

Unregistered design rights tend to have shorter shelf lives. Unregistered designs are useful in protecting "short-life products" (e.g., products within the fashion industry), because the registration process can be costly [30], "while 'classic' items with a longer life span may benefit from broader and longer registered design protection"[34].Unregistered design rights remain vital as they give fashion brands adequate protection for three years across the EU, "which is usually sufficient time to move on to the next design and to pay to fully register their entire range of designs for comprehensive protection" [19]. On the other hand, a registered design is more likely to act as a deterrent as there is no onus on a registered design right holder to prove infringement. It is also an easy right for selling or licensing relevant third parties.

\subsection{Legal Framework}

Before joining the EU, Croatia undertook a comprehensive process of aligning its legal order with the EU acquit communautaire. The Stabilization and Association Agreement (SPP) was undertaken to guarantee the scope of intellectual property protection of a similar scope existing in the EU, including the means to enforce these rights [35]. With the adoption of the Industrial Design Act and the 
amendments to this law, Croatia harmonized its legal order in this area with the acquit, thus fulfilling the commitments made to it by the SSP [36].

Pursuant to the provisions of the stabilization and association agreement between the European communities and their member states, on the one hand, and Serbia on the other [37], or with the provisions of the interim agreement on trade and trade issues between the European community on the one hand, and Serbia on the other, [38] the process of harmonizing Serbian law with EU law is in progress. The law on the legal protection of industrial design is fully harmonized with Directive 98/71/EC [39]. On the day of Serbia's accession, the EU will be able to fully implement Directive 98/71/EC with regard to the exhaustion law in the EU territory. The importance of the EU's intellectual property rights is also that those countries that are not currently members of the EU take decisions from the EU regulations when formulating their national legislation in this area.

As already mentioned, industrial design as the right of industrial property in most countries is acquired by registration based on the results of the conducted examination procedure for the design protection application for the authorized body (SIPO in Croatia). In Serbia, the application is submitted to the IPO. It is important to emphasize that the protection of industrial design refers exclusively to the outward appearance of the product, and the regulations on legal protection of design (including Croatian and Serbian laws) exclude the protection of the appearance of a product that is solely determined by the technical function of the product. Serbian legislation, as well as Croatian law, stipulates that, when determining the individual character of a design, the author's degree of freedom is taken into account when creating the design. According to modern design protection regulations, the design right holder has the exclusive right to use the registered design and prohibits a third person from doing so without their consent.

If all the prescribed conditions for registration are met, a decision on the registration of an industrial design is made, and the industrial design data are published in the official journal SIPO (Croatian Intellectual Property Bulletin). Also, in Serbia, this limited-term right is acquired in an administrative proceeding before a trusted authority, based on a decision on the recognition of rights and registration of the rights in the IPO industrial design register. With the accession of Croatia to the EU, a new intellectual property right was envisaged, which is an unregistered community design, which as of 2013 includes Croatia.

\section{Discussion}

Based on IPO data, in Serbia, by 2017, 4725 industrial designs were registered in total. Out of that number, 663 were registered based on applications submitted directly to IPOs and 4062 were registered on the basis of applications submitted by the Hague system. The IPO published, in its annual report, the number of industrial design applications in the period from 2011 to 2017 (Table 1) and the number of registered industrial designs in the period from 2011 to 2017 (Table 2).

Table 1. Structure of the applications of industrial design in the period from 2011 to 2017 in Serbia [40].

\begin{tabular}{ccccc}
\hline \multirow{2}{*}{ Year } & \multicolumn{2}{c}{ National Applications } & & \\
& \multicolumn{1}{c}{ Domestic Applications } & Foreign Applications & International Applications ${ }^{2}$ & Total $^{2}$ \\
\hline 2011 & 78 & 24 & 280 & 382 \\
2012 & 66 & 22 & 343 & 431 \\
2013 & 94 & 30 & 284 & 408 \\
2014 & 97 & 9 & 219 & 325 \\
2015 & 86 & 19 & 251 & 356 \\
2016 & 91 & 16 & 282 & 389 \\
2017 & 92 & 18 & 265 & 375 \\
\hline
\end{tabular}

1 Applications filed directly to theIntellectual Property Office (IPO). ${ }^{2}$ Applications filed through the International Bureau in Geneva. 
Table 2. Structure of the registered industrial design in the period from 2011 to 2017 in Serbia [40].

\begin{tabular}{ccccc}
\hline \multirow{2}{*}{ Year } & \multicolumn{2}{c}{ National Registrations $^{\mathbf{1}}$} & & \\
\cline { 2 - 4 } & Domestic Right Holders & Foreign Right Holders & International Registrations $^{2}$ & Total $^{2}$ \\
\hline 2011 & 60 & 19 & 255 & 334 \\
2012 & 49 & 19 & 319 & 387 \\
2013 & 38 & 19 & 293 & 350 \\
2014 & 58 & 35 & 208 & 301 \\
2015 & 48 & 10 & 229 & 287 \\
2016 & 82 & 13 & 251 & 346 \\
2017 & 70 & 27 & 247 & 344 \\
\hline
\end{tabular}

$1 \overline{\text { Industrial designs registered directly with the IPO. }{ }^{2} \text { Industrial designs registered through the International Bureau }}$ in Geneva.

If we observe only 2016, in this year, domestic and foreign applicants submitted 107 applications for industrial design directly to the IPO (Table 1). Also, Table 1 shows that, through the Hague system, 282 design applications were submitted, which involves33 applications more than in 2015 (about 12\%), and 201 industrial designs (about 21\%) more in relation to 2015.

The structure of the number of industrial design applications submitted directly to the IPO between domestic and foreign applicants during 2016 shows a much higher percentage of applications by domestic applicants (85\%). Of the total number of applications, domestic applicants filed 91 applications, while the foreign applicants submitted 16 applications for industrial design (Table 1).

Compared to the previous year, 2016, there was a significant increase in the number of requests for international registration of industrial designs based on the Hague system, filed through the IPO (110\% increase). This continued in 2017 [40].

The data show that, by the end of 2017, there were 4362 registered designs in the national procedure and through the Hague system in Croatia. Out of those, 1461were industrial design rights registered in the national proceedings before the SIPO and 2901through the Hague system.

The ability to protect industrial design in the territory of Croatia as part of a single EU market through the community design, which exists since Croatia's accession to the EU, significantly affected the decline in the number of applications for design protection in Croatia through national and international procedures. In 2017, this impact was even more pronounced than inthepreviousyearsofmembership (Table 3). In 2017, 158 applications for industrial design were received in the national procedure for registration of industrial design before the SIPO, which is $13 \%$ less compared to the previous year, and, as the SIPO points out," at the same time, the lowest annual number of submitted applications for industrial design in the national procedure in the last 15years." (Table 4) The assumption is that, in Serbia, after joining the EU, this will also be the result.

Table 3. Design applications in Croatia from 2011 to 2017 [41].

\begin{tabular}{ccccc}
\hline \multirow{2}{*}{ Year } & \multicolumn{2}{c}{ Number of Applications } \\
\cline { 2 - 4 } & Domestic Applications & Foreign Applications & International Applications (Hague Agreement) & Total \\
\hline 2011 & 275 & 37 & 374 & 686 \\
2012 & 285 & 34 & 322 & 690 \\
$2013^{*}$ & 215 & 18 & 81 & 255 \\
2014 & 210 & 3 & 74 & 270 \\
2015 & 182 & 13 & 67 & 256 \\
2016 & 181 & 1 & 225 \\
2017 & 157 & 1 &
\end{tabular}

* Croatia's accession to the European Union (EU).

The distribution of the number of design notifications submitted directly to the SIPO between applications by foreigners and applications by domestic applicants, in 2014, 2015, and 2016, shows not only the dominance of the share of applications by domestic applicants, but also the nominal decrease in the number of applications by domestic applicants, who submitted 157 applications or $13 \%$ in the previous year (Table 3). Table 3 shows that foreign applicants reported one application for industrial 
design in national proceedings before the SIPO in 2017, which represents the lowest recorded annual number of applications filed by foreign applicants.

Table 4. Number of designs contained in nationally filed design applications from 2011 to 2017 in Croatia [41].

\begin{tabular}{ccc}
\hline Year & Number of Applications & Number of Designs \\
\hline 2011 & 312 & 695 \\
2012 & 319 & 769 \\
$2013^{*}$ & 233 & 635 \\
2014 & 213 & 509 \\
2015 & 195 & 420 \\
2016 & 182 & 571 \\
2017 & 158 & 383 \\
\hline \multicolumn{3}{c}{}
\end{tabular}

All these data show that, after the EU accession, the citizens of Croatia, in addition tothe possibilities for design protection through national and international procedures, opted for the application of new forms of design protection.

However, for the overall picture of the number of applications for registration of design in the territory of Croatia, it should be taken into consideration that 26,047 applications for submission to the EUIPO in 2017 were submitted for registration of community designs related to the territory of Croatia. Based on this, it can be concluded that a total of 22,899 applications for registration of designs in the territory of Croatia were submitted in 2017, with the note that the EUIPO entirely keeps official records on registered community designs [41].

Nearly 85,000 designs per year are registered with the EUIPO [42]. Based on 315,000 designers in 2009 and, using the 2011 figures, this would indicate that 0.01 designers registered their designs in the United Kingdom (UK). In comparison to UK's designers, Anti Copying in Design (ACID), however, receives around 25,000 lodgments to its Intellectual Property Databank (copyright, designs, and unregistered trademarks) per year, reinforcing the evidence that the majority of UK's designers rely on unregistered EU and UK design rights (and copyright). Despite WIPO's report that industrial design filing activity during 2016 grew by $10.4 \%$ to an estimated 963,100 applications containing 1.2 million designs on average, this is still only 7547 per country, which is hardly a significant number of design registrations and only further reinforces the statement that the majority of global designers rely on unregistered design rights [43]. Therefore, in further research, it is necessary to analyze whether some designers in national legislations opt for unregistered design and in what number. However, it could be protected by legislation on trade secrets (EU Directive 2006/943 of the European parliament and of the council of 8 June 2016) or unfair competition; thus, it should be left for future research.

\section{Conclusions}

What makes Croatia and Serbia economically similar, aside from their former long mutual Yugoslavian history, can be limited to the existance of recidivation of state socialism, stagnant economic growth in recent years, and the high public debt of both countries. Both countries struggle with problems of counterfeiting and piracy.

The protection of industrial design is a significant market means which a producer can use to protect the investments into the development and production of a product. Industrial design as the right of industrial property in most countries is acquired by registration based on the results of the conducted examination procedure of the application for design protection by the competent state authority. The holder of a registered design right has the exclusive right to use a protected design and prohibits any third person from doing so without consent.

Unregistered design is acquired without a formal registration procedure, an appropriate disclosure of public design in the EU area. Rights based on unregistered design are narrower than rights arising 
from registered design and relate to prohibiting other persons from copying design. The duration of the unregistered design is three years, and cannot be extended. This form of design protection can be significant for the fashion industry in Serbia, which is characterized by a constant dynamic design change.

The empirical research allowed positively verifying the initial premise using the method of analogy: after the accession of Serbia to the EU, as well as of Croatia, physical and legal persons from Serbia will have several different forms of industrial design protection and unregistered community design available.

Also, since 2013 when Croatia joined the EU, Croatian sitizens and legal persons residing in Croatia can protect the registered design of the community directly with the EUIPO, and the stated data confirm that they used this approach significantly. Theyalso use the Hague system.It is important to point out that the effects of applications of registered community designs submitted and community designs acquired prior to the date of Croatia's admission to full EU membership are also extended to the territory of Croatia.

In addition to the already mentioned formal changes of the intellectual property system arising from the accession of the Croatia, and later Serbia, to the European Union, it is expected that full integration into the common market of the European Union and European professional network in the field of intellectual property will contribute to the strengthening of effective application of intellectual property in terms of raising the competitiveness of their economy, and further improvement of the mechanism for fighting against counterfeiting and piracy, which is the most common form of infringement of intellectual property, ensuring even more effective protection of the consumers.

Author Contributions: Conceptualization, N.L., S.S.; Investigation, N.L., M.D.M., M.Z.K., S.S. and M.C.; Formal analysis, N.L., M.C., M.Z.K.; Collected data: N.L., S.S., M.D.M., M.Z.K.; Methodology, M.Z.K., S.S., M.D.M. and M.C.; Project administration, M.Z.K.; Visualization, M.Z.K., M.D.M., M.C.; Writing—original draft, N.L.; Writing—review \& editing, N.L., M.D.M., S.S.; Supervision, N.L., S.S., M.D.M.; Validation, N.L., M.Z.K., S.S., M.C.

Funding: This research received no external funding.

Conflicts of Interest: The authors declare no conflicts of interest.

\section{References}

1. Zakin, M.; Stanisavljev, S.; Pečujlija, M.; Markoski, B.; Mitrović, V.; Vlahović, M. Impact of the Educational Attainment of the Knowledge Management Process in Serbian Textile Enterprises. Fibres Text. East. Eur. 2017, 25, 14-19. [CrossRef]

2. Đorđević, D.; Sajfert, D.; Gligorović, B. Quality Management Concept and Competitiveness of Serbian Companies. J.Eng. Manag. Compet. (JEMC) 2013, 3, 79-84.

3. Stanisavljev, S.; Ćoćkalo, D.; Klarin, M.; Spasojević Brkić, V.; Đorđević, D. Stohastic Model to Determine the Elements of the Production Cycle Time: Case of Serbian Textile Industry. Fibres Text. East. Eur. 2015, 23, 23-29. [CrossRef]

4. Urošević, S. Koncept klister-rešenje za opstanak malih i srednjih preduzeća u sektoru tekstila. Zbo. Rad. Tehnol. fak. Leskovcu 2011, 20, 252-260.

5. Perinčić, D. Zaštita potrošača od krivotvorenih i piratskih proizvoda. Strani Prav.Ziv. 2017, 2, 77-93.

6. Council Decision of 14 March 2005 on the Conclusion of the Bilateral Agreement between the European Community and the Republic of Serbia on Trade in Textile Products-OJ L90 of 08/04/2005. Available online: http:/ / ec.europa.eu/world/agreements/prepareCreateTreatiesWorkspace/ treatiesGeneralData.do?step=0\&redirect=true\&treatyId=3341 (accessed on 4 August 2018).

7. Chamber of Commerce of the Republic of Serbia. Available online: http:/ / www.pks.rs/PrivredaSrbije.aspx? $\mathrm{id}=16 \& \mathrm{p}=2 \&$ (accessed on 4 August 2018).

8. The Law on Confirmation of the Free Trade Agreement between the Republic of Serbia and the Republic of Turkey; Official Gazette of Republic of Serbia-International Treaties: Belgrade, Serbia, 2009; pp. 1-19.

9. Annual Report 2016; European Apparel and Textiles Confederation (Euratex): Brussels, Belgium, 2016.

10. Innovation Union. Europe 2020. Available online: http:/ / ec.europa.eu/research/innovation-union/index en.cfm?pg=home (accessed on 5 August 2018). 
11. Dziuba, R.; Jabłońska, M. Competitiveness of the Textile Sector of Croatia in Trade with the European Union. Fibres Text. East. Eur. 2017, 25, 14-18. [CrossRef]

12. Borghi, E.; Helg, R.; Tajoli, L. The Transatlantic Trade and Investment Partnership: Challenges and Opportunities for the Internal Market and Consumer Protection in the Area of Textiles and Labeling; European Parliament: Brussels, Belgium, 2015; p. 10.

13. Zelenika, R.; Grilec Kaurić, A. Ocjena ekonomskog položaja textilne i odjevne industrije u Republici Hrvatskoj. Misao Praksa 2011, 2, 136-139.

14. Agency for Investments and Competitiveness in Croatia. Available online: www.aik-invest.hr (accessed on 4 August 2018).

15. OECD/EUIPO. Trade in Counterfeit and Pirated Goods: Mapping the Economic Impact; OECD Publishing: Paris, France, 2016.

16. WIPO. Available online: http://www.wipo.int/edocs/mdocs/hague/en/ompi_di_san_11/ompi_di_san_ 11_14.pdf (accessed on 14 August 2018).

17. Boričić, B. O metodu analogije. Nastava Matematike 1998, 43, 1-6.

18. Negel, E. The Structure of Science, Problems in the Logic of Scientific Explanation; Harcourt, Brace and World, Inc.: New York, NY, USA, 1961.

19. Montalvo Witzburg, F. Protecting Fashion: A Comparative Analysis of Fashion Design Protection in the United States and the European Union. Law J. Int. Trademark Assoc. 2017, 107, 1131-1149.

20. Vlaškovic, B. Osnovi ostvarivanja Pravne Zaštite Pojedinih Vidova Industrijske Svojine; Pravo Industrijske Svojine: Belgrade, Serbia, 1990.

21. Varga, S. Pravo Industrijske Svojine; Alfagraf-NS: NoviSad, Serbia, 2008.

22. Miladinović, Z. Pravo Intelektualne Svojine; Pravni Fakultet Univerziteta u Kragujevcu: Kragujevac, Serbia, 2009.

23. Besarović, V. Pravo Intelektualne Svojine; Pravni fakultet Univerziteta u Beogradu: Belgrade, Serbia, 2005.

24. Fischer, F. Design Law in the European Fashion Sector; WIPO: Geneva, Switzerland, 2008.

25. Barazza, S. The individual character of a design: Freedom and 'the saturation of the state of the art'. J. Intellect. Prop. Law Pract. 2013, 8, 267-270. [CrossRef]

26. WIPO. The Hague Agreement Concerning the International Deposit of Industrial Designs (The Hague Act of 28 November 1960). Available online: https:/ / www.wipo.int/treaties/en/text.jsp?file_id=284501 (accessed on 24 August 2018).

27. EUR-lex. Directive 98/71/EC of the European Parliament and of the Council of 13 October 1998 on the legal Protection of Designs-OJL 289; European Union: Brussels, Belgium, 1998; pp. 28-35.

28. EUR-lex. Council Regulation (EC) No 6/2002 of 12 December 2001 on Community designs-OJL 3,5.1; European Union: Brussels, Belgium, 2002; pp. 1-24.

29. Varga, S. Vrste industrijskog dizajna. Pravno-Ekon. Pogl. 2001, 1, 1-13.

30. EUIPO. Designs in the European Union. Available online: https://euipo.europa.eu/ohimportal/en/designsin-the-european-union (accessed on 24 August 2018).

31. Annual Report 2006; European Apparel and Textiles Confederation (Euratex): Brussels, Belgium, 2006.

32. Cambridge Advanced Learner's Dictionary and Thesaurus. Available online: http://dictionary.cambridge. org/us/dictionary/british (accessed on 4 August 2018).

33. Raustiala, K.; Sprigman, C.J. The Piracy Paradox: Innovation and Intellectual Property in Fashion Design. Va. Law Rev. 2006, 92, 1687-1778.

34. Keymeulen, V.E. Copyrighting couture or counterfeit chic? Protecting fashion design: A comparative EU-US perspective. J. Intellect. Prop. Law Prac. 2012, 10, 728-737. [CrossRef]

35. Stabilization and Association Agreement between the Republic of Croatia, on the one hand, and the European Communities and Their Member States, on the other Hand. Available online: http:/ / www.mvep.hr/hr/hrvatska-i-europska-unija/hrvatska-i-europska-unija/proces-stabilizacije-ipridruzivanja-/sporazum-o-stabilizaciji-i-pridruzivanju/ (accessed on 4 September 2018).

36. Industrial Design Act, NN173/03,76/07,30/09,49/11,46/18, Croatia. Available online: http://www.zakon. $\mathrm{hr} / \mathrm{z} / 382 /$ Zakon-o-industrijskom-dizajnu (accessed on 14 September 2018).

37. Stabilization and Association Agreement between the European Communities and Their Member States, of the One Part, and the Republic of Serbia, of the Other Part; Official Gazette of Republic of Serbia: Belgrade, Serbia, 2008; pp. 1-834. 
38. EUR-lex. Interim Agreement on Trade and Trade-Related Matters between the European Community, on the One Part, and Republic of Serbia, on the Other Part; European Union: Brussels, Belgium, 2010; pp. 1-396.

39. Zakon o Pravnoj Zaštiti Indsutrijskog Dizajna (Sl. glasnik RS br.104/2009, 45/2015, 44/2018). Available online: https://www.paragraf.rs/propisi/zakon_o_pravnoj_zastiti_industrijskog_dizajna.html (accessed on 14 September 2018).

40. Annual Report 2016; Intellectual Property Office Republic of Serbia: Belgrade, Serbia, 2016.

41. Annual Report 2017; State Intellectual Property Office of the Republic of Croatia: Zagreb, Croatia, 2017.

42. Ljubojev, N.; Ivin, D. Basic characteristics of European Union Legislation in the Field of Industrial Desing Protection. In Proceedings of the Scientific-Profesional Conference Textile Science and Economy V, Technical Faculty MihajloPupin, Zrenjanin, Serbia, 5-6 November 2013; Volume 5, pp. 269-274.

43. Anti-Copying in Design: Brexit Evidence to Support Parity of UK Unregistered Design Rights with EU Unregistered Designs Evidence and Findings Following ACID Research Questionnaire. Available online: https:/ / www.acid.uk.com/wp-content/uploads/2017/12/brexit-evidence-to-supportparity-of-uk-udr-with-eu-udr-1.pdf (accessed on 24 September 2018).

(C) 2019 by the authors. Licensee MDPI, Basel, Switzerland. This article is an open access article distributed under the terms and conditions of the Creative Commons Attribution (CC BY) license (http://creativecommons.org/licenses/by/4.0/). 